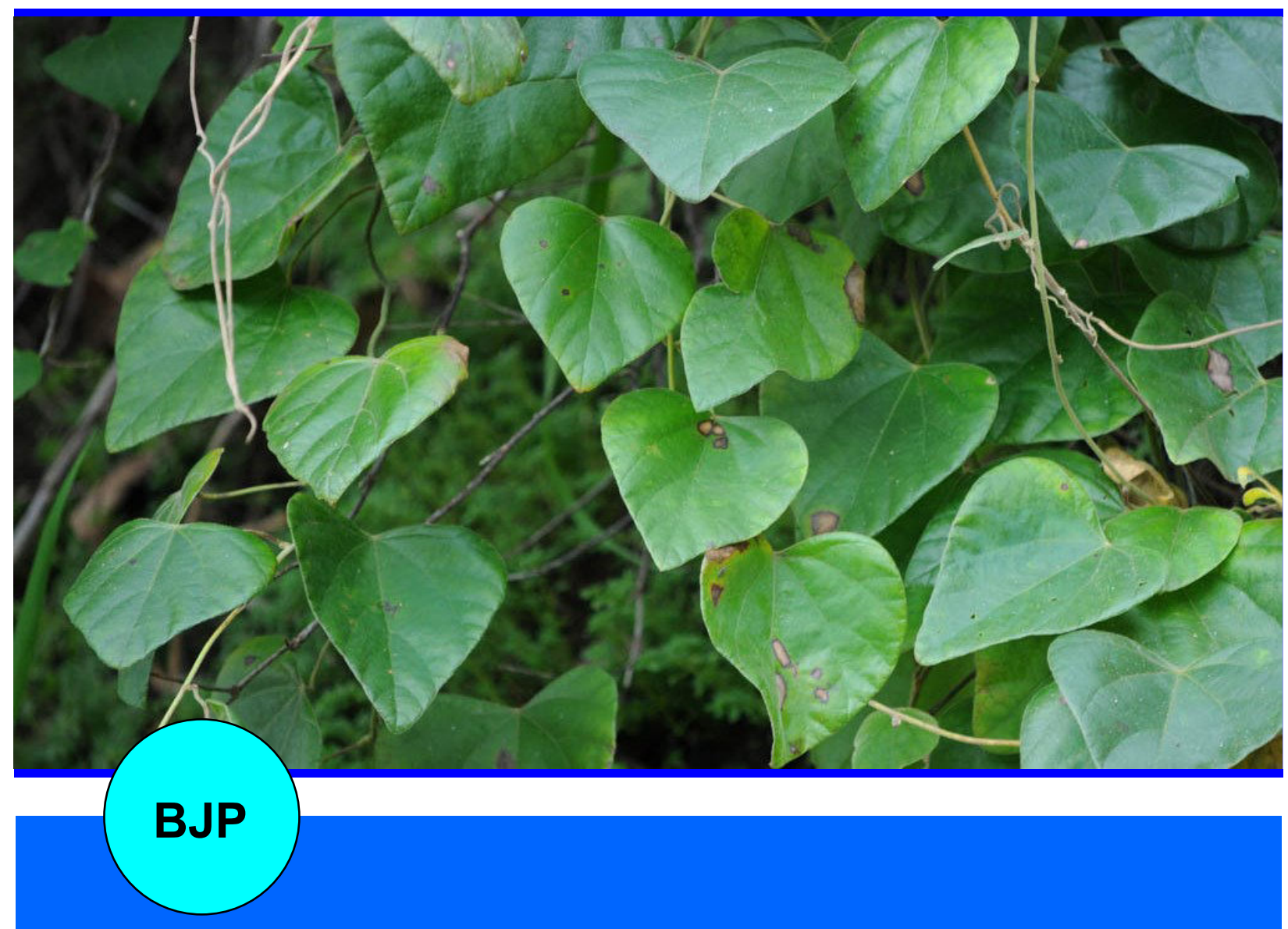

Bangladesh Journal of Pharmacology

Research Article

Effect of Pericampylus glaucus on plasma glucose concentration and lipid profile in streptozotocininduced diabetic rats 
Abstracted/indexed in Academic Search Complete, Asia Journals Online, Bangladesh Journals Online, Biological Abstracts, BIOSIS Previews, CAB Abstracts, Current Abstracts, Directory of Open Access Journals, EMBASE/Excerpta Medica, Google Scholar, HINARI (WHO), International Pharmaceutical Abstracts, Open J-gate, Science Citation Index Expanded, SCOPUS and Social Sciences Citation Index;

ISSN: $1991-0088$

\title{
Effect of Pericampylus glaucus on plasma glucose concentration and lipid profile in streptozotocin-induced diabetic rats
}

\author{
Muhammad Kifayatullah and Pinaki Sengupta
}

Faculty of Pharmacy, Lincoln University College, 47301,Petaling Jaya, Selangor, Malaysia.

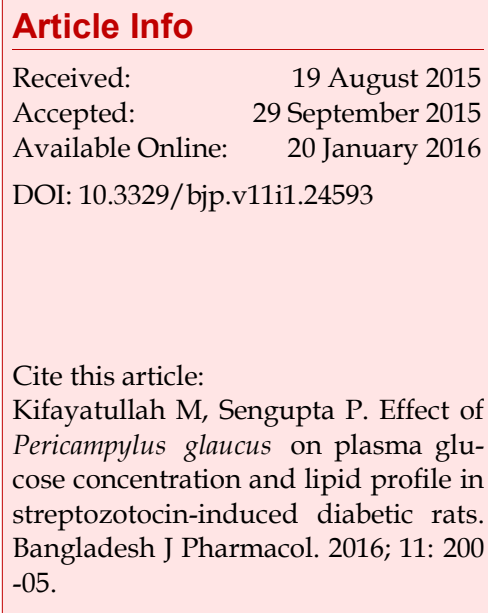

\section{Abstract}

The purpose of this study was to evaluate the effects of Pericampylus glaucus extract on plasma glucose concentration and lipid profile in normal and streptozotocin-induced diabetic rats. The ethanolic extract were administered orally at three different doses $(400,600$ and $800 \mathrm{mg} / \mathrm{kg})$ and glibenclamide (20 $\mathrm{mg} / \mathrm{kg}$ p.o.) for 21 days after 72 hours of streptozotocin injection. During the short- and long-term studies, the extract was found to possess significant $(\mathrm{p}<0.01, \mathrm{p}<0.001)$ anti-diabetic activity in normal and diabetic rats compared with untreated normal and untreated diabetic group. It also caused reduction in the level of total cholesterol, triglyceride, and LDL etc. and improvement in the HDL level compared with untreated diabetic rats. Reduction in the fasting blood sugar, cholesterol, triglyceride, urea, LDL, creatinine levels and improvement in the HDL by P. glaucus indicates that plant has anti-diabetic activity along with anti hyperlipidemic efficacy and provides a scientific rationale for the use.

\section{Introduction}

According to statistical report around, 382 million people suffered from diabetes mellitus worldwide. It is a chronic metabolic disorder characterized with biochemical alterations of glucose, urine excretion and lipid metabolism (Kamboj et al., 2013). Two main types of diabetes mellitus reported, Type I is commonly known as insulin dependent diabetes mellitus (IDDM) and Type II, is called non-insulin dependent diabetes mellitus (NIDDM) (Patel et al., 2011). A number of side effects have been observed with the use synthetic antidiabetic drugs. The use of natural remedies for the treatment of diabetes has long history. The genus Pericampylus glaucus Lam Merr belongs to the family of Menispermaceae, commonly found in Malaysia (Wiart, 2006). The roots are claimed to be effective against lowering high lipid level and diabetes in Malaysia (Ong et al., 2011). The stems and roots effectively to stops bleeding, arthritis, sore throat, productive cough, colds, headache, abdominal pain, and abdominal distention
(Li, 2006).The whole plant, fruits, stem and leaves are also connected for various ailments like for the relief of loss of movement tongue, fever, joint pain, muscles pain, diabetes, constipation, snake biting and edema (Jahan et al., 2010, Azad et al., 2014).

Therefore, the present study was aim to determine the effect of $P$. glaucus on plasma glucose concentration and lipid profiles in streptozotocin-induced diabetic rats.

\section{Materials and Methods \\ Collection of plants and ethanol extraction}

P. glaucus was collected in the month of September 2014 from Negeri Sembilan, Malaysia, village Jeram Kedah. It was authenticated by Ms. Tan Ai Lee at Forest Research Institute Malaysia (FRIM), Malaysia (voucher specimen herbarium number SBID: 014/14) was deposited to Faculty of Pharmacy as a reference. After washing, the leaves were removed and dried in shade 
for 20 days. The shade dried leaves were converted into coarse powder with the help of blender. The powder was extracted by continuous hot extraction using the soxlet apparatus at a temperature of $78^{\circ} \mathrm{C}$ for 48 hours using $95 \%$ ethanol. The extract was then concentrated under reduce pressure through rotary evaporator $(\mathrm{N}$ 10000, Eyela, Japan) and preserved in a desiccator for further studies.

\section{Drugs and chemicals}

Streptozotocin and glibenclamide was purchased from Sigma-Aldrich Bio Syn Tech Malaysia Group. Analytical grade of chemicals and various solvents for extraction were used (E. Merck (Germany), Astral Laboratory Chemicals, $\mathrm{R} / \mathrm{M}$ Chemicals, Loba Chemicals, Alpha Chemika and Sigma-Aldrich Co. (UK)]. The Biochemical parameters were determined through biochemistry analyzer model (BA-D200A). Standard kit Bio-Diagnostics Bhd Malaysia was also used.

\section{Test animal}

Sprague Dawley rats of both sex (90-110 g) were used and were kept in the animal house of the Department of Pharmacology, Lincoln University College, Malaysia. The animals were kept in plastic cages $(34 \times 47 \times 18$ $\mathrm{cm}^{3}$ ) in an air conditioned environment with five animals in each cage and maintained at room temperature of $25^{\circ} \mathrm{C} \pm 2{ }^{\circ} \mathrm{C}$ with relative humidity $(60 \pm$ $10 \%)$ under 12 hours night and light cycle. All the animals were kept on fasting before experiment except free excess to water.

\section{Induction of diabetes}

Diabetes was induced in fasted rats by a single dose of streptozotocin $50 \mathrm{mg} / \mathrm{kg}$ body weight through i.p routes dissolved in freshly prepared $0.01 \mathrm{M}$ citrate buffer, pH 4.5 (Aslan et al., 2007). After 72 hours rats showing fasting blood glucose more than (fasting blood glucose $\geq 250 \mathrm{mg} / \mathrm{dL}$ or $14 \mathrm{mmol} / \mathrm{L}$ ) were considered to be diabetic and selected in the experiment.

\section{Dose selection}

Three doses 400, 600 and $800 \mathrm{mg} / \mathrm{kg}$ body weight p.o. were selected on the basis of previous acute toxicity studies (Kifayatullah et al., 2015). Effect of P. glaucus on blood glucose in normal and streptozotocin-induced diabetic rats (short-term study)

\section{Normal rats}

Rats (90-110 g) were divided into five groups of normal control, crude drug treated and glibenclamide-treated animals $(n=5)$. Crude drug treated group was subdivided into three groups. The $1^{\text {st }}$ group was consider as a normal group received only normal saline. The $2^{\text {nd }}$ standard group received gliben-clamide at a dose of $0.02 \mathrm{~g} / \mathrm{kg}$ and crude drug-treated I, crude drugtreated II and crude drug-treated III received the extract of P. glaucus at a dose of 400, 600 and $800 \mathrm{mg} / \mathrm{kg}$. All the administration was done by gastric intubation using a force feeding needle dissolved in $20 \mathrm{~mL} / \mathrm{kg}$ of normal saline. Blood samples were collected from the tail vein at $0,2,4$ and 6 hours after the administration of $P$. glaucus extracts and glibenclamide and the blood glucose levels were determined by using glucose oxidize standard kits.

\section{Streptozotocin-induced diabetic rats}

The same procedure of grouping was adopted for streptozotocin-induced diabetic rats by adding one untreated diabetic group. Adult rats were divided into six groups of $\mathrm{n}=5$ of normal control, crude drug treated, glibenclamide and untreated diabetic control. The $1^{\text {st }}$ group was consider as a normal group. The $2^{\text {nd }}$ and $3^{\text {rd }}$ diabetic groups were consider as diabetic untreated and standard group received glibenclamide. Group crude drug-treated I, crude drug-treated II and crude drug-treated III diabetic received the extract of $P$. glaucusat a dose of 400, 600 and $800 \mathrm{mg} / \mathrm{kg}$. After an overnight fast streptozotocin-induced diabetic treated rat groups received the ethanolic extract of $P$. glaucus at a dose of 400,600 and $800 \mathrm{mg} / \mathrm{kg}$ and glibenclamide at a dose of $20 \mathrm{mg} / \mathrm{kg}$. Blood samples were collected from the tail vein at $0,2,4$ and 6 hours after the administration of P. glaucus extracts and glibenclamide and the blood glucose levels were determined by using glucose oxidize standard kits.

Effect of P. glaucus on blood glucose and lipid profile in normal and streptozotocin-induced diabetic rats (chronic treatment model)

The streptozotocin-induced diabetic rats were divided into 5 groups of six in each. Group I: Normal control group received normal saline $20 \mathrm{~mL} / \mathrm{kg}$, p.o.; Group II: Diabetic untreated rats; Group III: Diabetic treated with standard glibenclamide (0.02 g / kg b.w/day, p.o.); Group IV: Diabetic treated P. glaucus $(800 \mathrm{mg} / \mathrm{kg} /$ day, p.o.); Group IV: Diabetic treated P. glaucus (600 mg/kg/day, p.o.); Group IV: Diabetic treated $P$. glaucus ( $400 \mathrm{mg} / \mathrm{kg} /$ day, p.o.)

The treatment was continued for a period of 21 days by gastric intubation using oral gavage.

\section{Biochemical estimation}

Blood samples were collected from tail veins before the start of the treatment and on $0,7^{\text {th }}, 14^{\text {th }}$ and $21^{\text {th }}$ days of the treatment and fasting blood glucose levels were estimated. All the five groups of rats were sacrificed on the $22^{\text {th }}$ day after an overnight fast, by anesthetizing with ether and further by cardiac puncture blood were collected in test tube with anti-coagulant agents.

\section{Analytical procedure}

Blood glucose estimation was determined by glucose oxidase-peroxidase method using a standard kit obtained from Bio-Diagnostics Sdn. Bhd. Malaysia. The 
biochemical analysis was done on serum after centrifugation of collected blood for both control and extract treated groups. All analyses were determined on using biochemistry analyzer (model BA-D200A).

\section{Statistical analysis}

Statistical analysis was performed as mean of variance \pm SEM $(n=5)$ followed by ANOVA test using Graph Pad Prism and for multiple comparison test among the groups, Bonferroni test was performed. A probability level of $\mathrm{p}<0.05$ was accepted statistically.

\section{Results}

\section{Effect on blood glucose in normal and diabetic rats}

The fasting blood glucose levels of diabetic untreated rats were significantly higher than those of normal untreated rats (Table I and Table II). The crude ethanolic extracts of $P$. glaucus produced a dosedependent glucose lowering effect in normal and diabetic rats, however the crude ethanolic extracts at a dose of $800 \mathrm{mg} / \mathrm{kg}$ produced significant $(\mathrm{p}<0.01)$ fall in blood glucose level $(4.2 \pm 0.5 \mathrm{mmol} / \mathrm{L})$, respectively in normal crude drug treated rats after 4 hours that became significant $(3.7 \pm 0.1 ; \mathrm{c} p<0.001)$ after 6 hours when compared to normal group. In diabetic rat, the ethanolic extracts at same dosage of $800 \mathrm{mg} / \mathrm{kg}$ produced reduction in blood glucose (14.4 $\pm 0.2 ; \mathrm{p}<$ $0.05)$ after 2 hours of the treatment that became significant $(p<0.001)$ after 4 hours when compared to untreated diabetic control group.

Effect of P. glaucus and glibenclamide on blood glucose levels and lipid profiles in diabetic rats

The effect of crude ethanolic extract treated groups on blood glucose levels and lipid profiles are shown in Figure 1. After the administration of streptozotocin (0 day), the fasting blood glucose levels of test rats increased significantly $(\mathrm{p}<0.001)$ compared to normal control. Seven days after crude extract treatment, the blood glucose level of the diabetic control and crude extract-treated Group I (400 mg/ $\mathrm{kg}$ ) and crude extracttreated Group II $(600 \mathrm{mg} / \mathrm{kg})$ remained high, while that of crude extract-treated Group III at a dose of $800 \mathrm{mg} /$ $\mathrm{kg}$ reduced significantly $(\mathrm{p}<0.01)$ the blood glucose level of $13.9 \pm 0.2 \mathrm{mmol} / \mathrm{L}$, when compared to diabetic

\section{Table I}

Effect of $P$. glaucus on blood glucose level in normal rats

\begin{tabular}{|c|c|c|c|c|}
\hline \multirow[t]{2}{*}{ Treatment } & \multicolumn{4}{|c|}{$\begin{array}{l}\text { Blood glucose level } \\
(\mathrm{mmol} / \mathrm{L})\end{array}$} \\
\hline & 0 hour & 2 hours & 4 hours & 6 hours \\
\hline Normal control & $5.8 \pm 0.1$ & $5.6 \pm 0.3$ & $5.3 \pm 0.5$ & $5.2 \pm 0.1$ \\
\hline Extract $(400 \mathrm{mg} / \mathrm{kg})$ & $5.9 \pm 0.2$ & $5.3 \pm 0.1$ & $4.8 \pm 0.2$ & $4.6 \pm 0.2$ \\
\hline Extract $(600 \mathrm{mg} / \mathrm{kg})$ & $5.4 \pm 0.1$ & $4.9 \pm 0.1$ & $4.3 \pm 0.4^{a}$ & $4.0 \pm 0.9 a$ \\
\hline Extract $(800 \mathrm{mg} / \mathrm{kg})$ & $5.4 \pm 0.2$ & $4.9 \pm 0.0$ & $4.2 \pm 0.5^{\mathrm{a}}$ & $3.7 \pm 0.1^{b}$ \\
\hline Glibinclamide $(20 \mathrm{mg} / \mathrm{kg})$ & $5.7 \pm 0.1$ & $4.9 \pm 0.0$ & $4.1 \pm 0.5$ & $3.6 \pm 0.1$ \\
\hline
\end{tabular}

Data are expressed as mean $\pm \mathrm{SEM} ; \mathrm{n}=5$; ${ }^{\mathrm{p}}<<0.01$, ${ }^{\mathrm{b}} \mathrm{p}<0.001$ significant as compared to normal control, statistical test employed was ANOVA followed by Bonferroni test

\section{Table II}

Effect of $P$. glaucus on blood glucose in streptozotocin-induced rats

\begin{tabular}{|c|c|c|c|c|}
\hline \multirow[t]{2}{*}{ Treatment } & \multicolumn{4}{|c|}{$\begin{array}{l}\text { Blood glucose level } \\
\qquad(\mathrm{mmol} / \mathrm{L})\end{array}$} \\
\hline & 0 hour & 2 hours & 4 hours & 6 hours \\
\hline Diabetic control & $15.8 \pm 0.9$ & $15.6 \pm 0.3$ & $15.3 \pm 0.5$ & $15.1 \pm 0.1$ \\
\hline Extract $(400$ mg/kg) & $15.9 \pm 0.2$ & $15.0 \pm 0.1$ & $14.4 \pm 0.2^{\mathrm{a}}$ & $13.9 \pm 0.2^{b}$ \\
\hline Extract $(600 \mathrm{mg} / \mathrm{kg})$ & $15.4 \pm 0.2$ & $14.7 \pm 0.9$ & $14.1 \pm 02^{b}$ & $12.7 \pm 0.2 c$ \\
\hline Extract $(800 \mathrm{mg} / \mathrm{kg})$ & $15.4 \pm 0.2$ & $14.4 \pm 0.2^{b}$ & $13.4 \pm 0.0^{c}$ & $12.4 \pm 0.2^{c}$ \\
\hline Glibinclamide 20 mg/kg & $15.7 \pm 0.1$ & $13.9 \pm 0.2$ & $13.0 \pm 0.1$ & $11.7 \pm 0.0$ \\
\hline
\end{tabular}

Data are expressed as mean $\pm \mathrm{SEM} ; \mathrm{n}=5$; ap $<0.05$, $\mathrm{b} p<0.01, \mathrm{c} p<0.001$ significant as compared to diabetic control, statistical test employed was ANOVA followed by Bonferroni test 


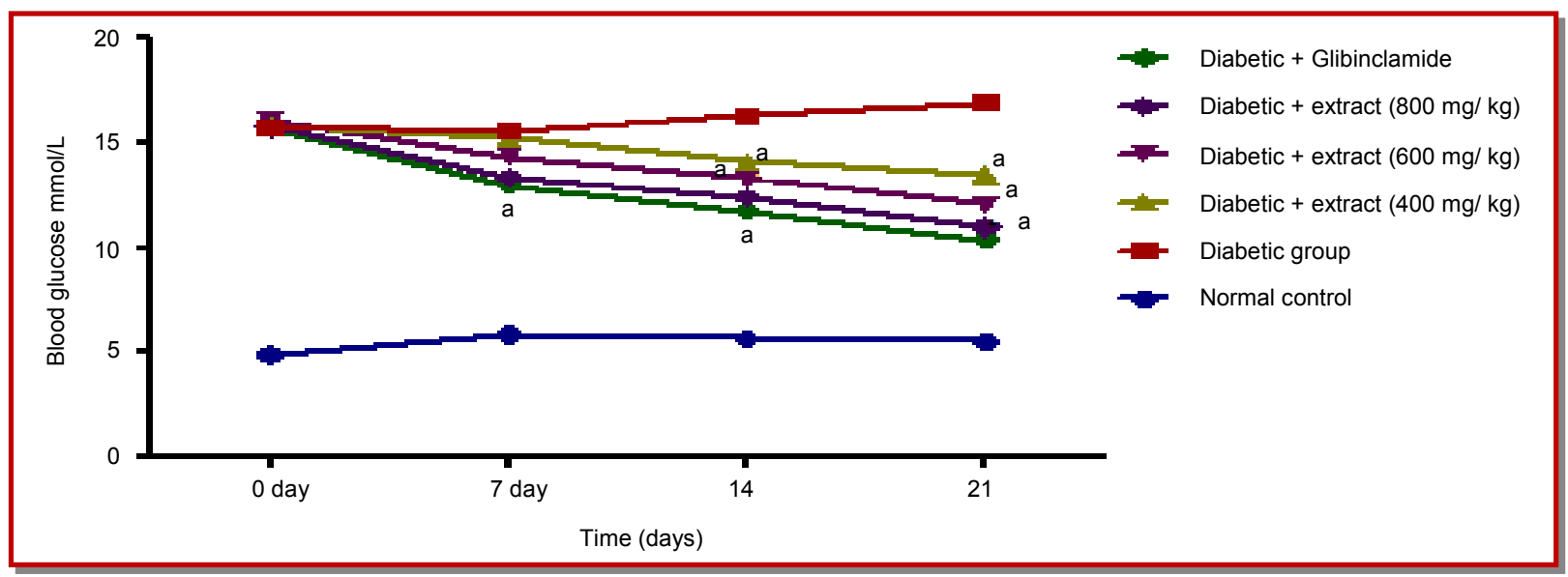

Figure 1: Effect of oral administration of ethanolic extract of Pericampylus glaucus and glibenclamide on plasma glucose level of streptozotocin-induced diabetic rats

Data are expressed as mean \pm SEM; $n=5$; ${ }^{2} p<0.001$ significant as compared to diabetic control, statistical test employed was ANOVA followed bmy Bonferroni test

\section{Table III}

\section{Effect of ethanolic extract of P. glaucus on serum lipid profiles in diabetic rats}

\begin{tabular}{|c|c|c|c|c|c|c|}
\hline Serum lipids profile & $\begin{array}{c}\text { Total Cho- } \\
\text { lesterol } \\
(\mathrm{mmol} / \mathrm{L})\end{array}$ & $\begin{array}{l}\text { Triglyceride } \\
(\mathrm{mmol} / \mathrm{L})\end{array}$ & $\begin{array}{c}\mathrm{LDL} \\
(\mathrm{mmol} / \mathrm{L})\end{array}$ & $\begin{array}{c}\text { HDL } \\
(\mathrm{mmol} / \mathrm{L})\end{array}$ & $\begin{array}{c}\text { Urea } \\
(\mathrm{mmol} / \mathrm{L})\end{array}$ & $\begin{array}{l}\text { Creatinine } \\
(\mathrm{mmol} / \mathrm{L})\end{array}$ \\
\hline Diabetic group & $7.1 \pm 0.4$ & $8.2 \pm 0.3$ & $4.6 \pm 0.4$ & $0.6 \pm 0.1$ & $3.3 \pm 0.4$ & $1.5 \pm 0.0$ \\
\hline Normal group & $1.5 \pm 0.1$ & $5.3 \pm 0.2$ & $2.3 \pm 0.1$ & $2.2 \pm 0.0$ & $1.8 \pm 0.1$ & $0.7 \pm 0.01$ \\
\hline Diabetic + extract $(400 \mathrm{mg} / \mathrm{kg})$ & $5.2 \pm 0.2^{c}$ & $4.5 \pm 0.4^{b}$ & $3.3 \pm 0.3 c$ & $1.4 \pm 0.2$ & $3.1 \pm 0.15$ & $0.6 \pm 0.05$ \\
\hline Diabetic + extract $(600 \mathrm{mg} / \mathrm{kg})$ & $4.1 \pm 0.1 \mathrm{c}$ & $3.6 \pm 0.1 c$ & $3.2 \pm 0.2^{b}$ & $1.7 \pm 0.2^{\mathrm{a}}$ & $2.7 \pm 0.0$ & $0.4 \pm 0.1^{\mathrm{a}}$ \\
\hline Diabetic + extract $(800 \mathrm{mg} / \mathrm{kg})$ & $3.8 \pm 0.2^{c}$ & $3.1 \pm 0.4^{c}$ & $2.5 \pm 0.3^{c}$ & $2.10 \pm 0.1^{b}$ & $2.2 \pm 0.0^{\mathrm{a}}$ & $0.1 \pm 0.0^{\mathrm{b}}$ \\
\hline Diabetic + Glibenclamide & $2.9 \pm 0.2$ & $2.90 \pm 0.7$ & $2.20 \pm 0.1$ & $2.30 \pm 0.2$ & $2.18 \pm 0.0$ & $0.07 \pm 0.0$ \\
\hline
\end{tabular}

Data are expressed as mean $\pm \mathrm{SEM} ; \mathrm{n}=5$; a $<0.05$, bp $<0.01, \mathrm{c} p<0.001$ significant as compared to diabetic control, statistical test employed was ANOVA followed by Bonferroni test

control $15.7 \pm 0.3 \mathrm{mmol} / \mathrm{L}$. After 14 days, significant $(\mathrm{p}<0.01)(14.2 \pm 0.3,13.3 \pm 0.4)$ reduction in blood glucose was found in crude drug treated 1 and crude drug treated 2 that became significant $\mathrm{p}<0.001(13.5 \pm$ $0.1,12.1 \pm 0.1 \mathrm{mmol} / \mathrm{L})$, whereas significant $\mathrm{p}<0.001$ $(12.4 \pm 0.2,11.0 \pm 0.1 \mathrm{mmol} / \mathrm{L})$, reduction in blood glucose level was found in crude drug treated 3 (800 $\mathrm{mg} / \mathrm{kg}$ ), that was sustained till the end of the study when compared to diabetic control group.

Table III indicates the serum lipids levels of total cholesterol, triglycerides, low density lipoprotein, urea, creatinine and high density lipoproteinin normal and experimental streptozotocin-induced diabetic animals in each group. As presented in Table III, the diabetic untreated group had significant elevation of total triglyceride, cholesterol, low density lipoprotein, urea, creatinine and reduction in high density lipoprotein levels compared to normal control group. The diabetic group treated with crude ethanolic plant extract at a dose of 400 and $800 \mathrm{mg} / \mathrm{kg}$ produced significant reduction in the level of total cholesterol, Low density Lipoprotein, triglycerides and significant improvement in high density lipoprotein, while non-significant in urea and creatinine level when compared to diabetic untreated group. The diabetic group treated with crude extract at a dose of $800 \mathrm{mg} / \mathrm{kg}$ produced significant reduction in the level of total cholesterol, low density lipoprotein, triglycerides, urea, creatinine and significant improvement in high density lipoprotein level.

\section{Discussion}

The present study confirmed the scientific evidence for the safe use of ethanolic extract of P. glaucus against high blood glucose level and serum lipid profile in normal and streptozotocin-induced diabetic rats. This falls in blood glucose level might be due to the direct stimulation of the secretion of insulin that promotes uptake of glucose metabolism and restore the 
remaining beta cells (Ali et al., 1993). An increase in the lipid content of serum was found in streptozotocininduced diabetic rats. The crude ethanolic extract produced a dose-dependent reduction in total cholesterol, triglyceride, low density lipoprotein- cholesterol levels, creatinine and increase in high density lipoprotein value. However, the crude plant extract of P. glaucus at a dose of $800 \mathrm{mg} / \mathrm{kg}$ produced significant reduction in total cholesterol, triglyceride, low density lipoprotein, urea, creatinine increased in high density lipoprotein levels in treated diabetic rats compared to untreated diabetic rats which will definitely reduce the complications associated with diabetes. The increased level of the total serum cholesterol, triglyceride, low density lipoprotein levels and decreased in high density lipoprotein level in the streptozotocin-induced diabetic animals might be due to over production of low density lipoprotein by the liver due to the stimulation of hepatic triglyceride synthesis, increased influx of free fatty acids from peripheral accumulation (Adiels et al., 2008). In untreated diabetic rats significantly increased $(c p<0.001)$ in blood cholesterol, urea, triglyceride, creatinine and low density lipoprotein were observed. Changes in lipid profiles might be due sensitivity of hormone lipase action, that promotes break down of lipids and result increase in free fatty acids level, which is subsequently catabolized to acetyl CoA (Edet et al., 2015). The lowering of plasma total cholesterol, triglyceride and low density lipoprotein-cholesterol levels and significant increase in high density lipoprotein-cholesterol level in the treated animals clearly confirmed the presence of hypolipidemic agents in the extracts of $P$. glaucus and standard drug gibenclamide compared to untreated diabetic rats could be inactiva-ting HMG-CoA reductase. The presence of secondary metabolites such as polyphenols, alkaloids, flavonoid, tannins and terpenoidin P. glaucus extract may contri-bute in protecting the $\beta$ cells of pancreas and thus producing hypoglycemic and hypolipidemic activity (Juárez-Rojop et al., 2014). The ability of the extracts to manage hyperlipidemia is a potential beneficial effect on cardiovascular risk factors which is a major cause of death in diabetes mellitus (Amaechi et al., 2015). This might be due to insulin secretagogue action by crude extract $P$. glaucus, preventing the renal damage in streptozotocin-induced diabetic rats.

\section{Conclusion}

Current investigation justifies the traditional use of $P$. glaucus Lam Merr in lowering of blood glucose level and lipid profiles.

\section{Ethical Issue}

The animals used for the experiment were approved by animal ethics committee of the Lincoln University College, Malaysia.

\section{Acknowledgement}

The authors are grateful to Prof. Mohd Shahimi Mustapha, Deputy Vice-chancellor, Research and Innovation and Dr. Arindam Das, Director, Center for Postgraduates Studies, Lincoln University College, Malaysia for providing financial and facility for this study.

\section{References}

Adiels M, Olofsson SO, Taskinen MR, Borén J. Overproduction of very low density lipoproteins is the hallmark of the dyslipidemia in the metabolic syndrome. Arterioscler Thromb Vasc Biol. 2008: 28; 1225-36.

Ali L, Khan AK, Mamun MIR, Mosihuzzaman M, Nahar N, Nur-E-Alam M, Rokeya B. Studies on hypoglycemic effects of fruit pulp, seed, and whole plant of Momordica charantia on normal and diabetic model rats. Planta Medica. 1993: 59; 408-12.

Amaechi D, Udosen E, Edet E, Asanga E, Mbakwe I. Lipid profile status of streptozotocin induced diabetic rats treated with ethanolic leaf extract of Solenostemon monostachyus. J Med Plants Res. 2015: 9; 289-93.

Aslan M, Orhan D, Orhan N, Sezik E, Yesilada E. In vivo antidiabetic and antioxidant potential of Helichrysum plicatum spp. plicatum capitulums in streptozotocin-induced-diabetic rats. Journal of Ethnopharmacology.2007: 109; 54-59.

Azad A, Mahmud MR, Parvin A, Chakrabortty A, Akter F, Moury SI, Anny IP, Tarannom SR, Joy S, Chowdhury S. Medicinal plants of a Santal tribal healer in Dinajpur District, Bangladesh. World J Pharm Pharmaceut Sci. 2014: 3; 1597606.

Edet A, Amaechi D, Udosen E, Uboh F. Evaluation of the effect of ethanolic leaf extract of Solenostemon monostachyus on blood glucose and liver enzymes in stz induced diabetic rats. Eur Sci J. 2015: 11; 1857-81.

Jahan R, Khatun M, Nahar N, Jahan F, Chowdhury A, Nahar A, Seraj S, Mahal M, Khatun Z, Rahmatullah M. Use of Menispermaceae family plants in folk medicine of Bangladesh. Adv Nat Appl Sci. 2010: 4; 1-9.

Kamboj A, Kumar S, Kumar V. Evaluation of anti-diabetic activity of hydroalcoholic extract of Cestrum nocturnum leaves in streptozotocin-induced diabetic rats. Adv Pharmacol Sci. 2013: 5; 105-12.

Kifayatullah M, Mustafa M.S, Sengupta P, Sarker MMR, Das A, Das SK. Evaluation of the acute and sub-acute toxicity of the ethanolic extract of Pericampylus glaucus (Lam.) Merr. in BALB/c mice. J Acute Dis. 2015: 4; 309-15.

Li TSC. Taiwanese native medicinal plants: Phytopharmacology and therapeutic values. CRC Press, 2006, pp 80-81.

Ong H, Chua S, Milow P. Ethnomedicinal plants used by the Temuan villagers in Kampung Jeram Kedah, Negeri Sembilan, Malaysia. Ethno Med. 2011: 5; 95-100. 
Patel D, Kumar R, Prasad S, Sairam K, Hemalatha S. Antidiabetic and in vitro anti-oxidant potential of Hybanthus enneaspermus (Linn) F. Muell in streptozotocin-induced diabetic rats. Asian Pac J Trop Biomed. 2011: 1; 316-22.

Juárez-Rojop IE, Tovilla-Zárate CA, Aguilar-Domínguez DE, Roa-de la Fuente LF, Lobato-García CE, Blé-Castillo JL,
López-Meraz L, Díaz-Zagoya JC, Bermúdez-Ocaña DY. Phytochemical screening and hypoglycemic activity of Carica papaya leaf in streptozotocin-induced diabetic rats. Revista Brasileira de Farmacognosia. 2014: 24; 341-47.

Wiart C. Medicinal plants of Asia and the Pacific. CRC Press. 2006.

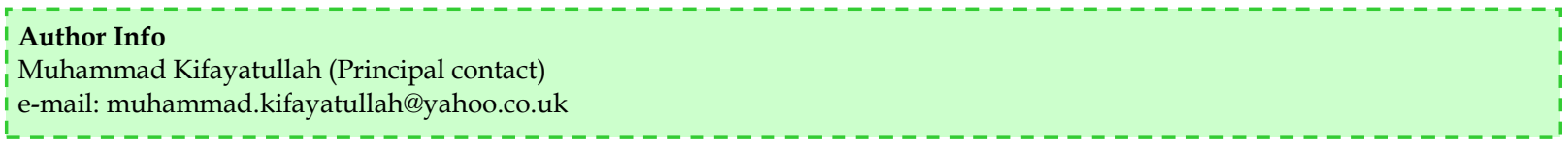




\section{Your feedback about this paper}

1. Number of times you have read this paper 0

2. Quality of paper Click

3. Your comments

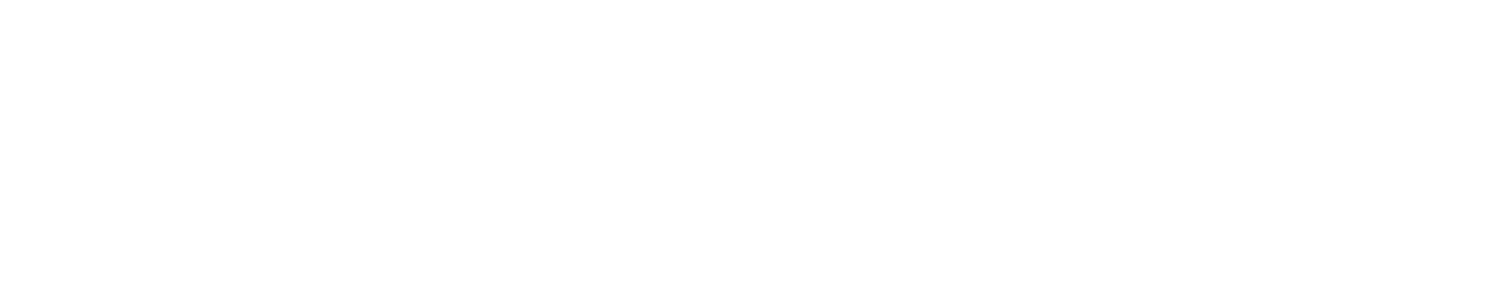

